\title{
A Comparative Analysis of Nutrients and Mineral Elements Content of Andropogon gayanus Kunth and Pennisetum pedicellatum Trin
}

\author{
${ }^{*}$ A.F. Waziri, S.A. Anka, A.Y. Bala and H. Shehu \\ Department of Biological Sciences, Usmanu Danfodiyo University, Sokoto, Nigeria \\ [Corresponding author: Email ; aminubala2001@yahoo.com. 粱: +2348035989824]
}

\begin{abstract}
Comparative studies on the nutrients and mineral elements content of the two grass species was conducted at Gangam Rangeland, Shagari L.G.A., Sokoto state. Sokoto lies on latitude $12.00^{\circ}$ and $13.60^{\circ} \mathrm{N}$ and longitude $4.80^{\circ}$ and $6.50^{\circ} \mathrm{E}$ and altitude $350 \mathrm{~m}$ above sea level. The result show that $P$. pedicellatum had high crude protein (Cp) ad crude fibre (Cf) content than A. gayanus. The high $\mathrm{Cp}$ content was attributed to its leafy nature (having abundant leaves) as $\mathrm{Cp}$ is more concentrated in leaves, whereas the high Cf content was possibly due to its stemmy nature particularly at the end of the growing period. However, in terms of Ether extract (Ee) and Ash content, A. gayanus had more. The high Ash content was probably as a result of high mineral elements content of the grass species. On the other hand, $A$. gayanus had high Phosphorus (P), Potassium (K), Magnesium (Mg), Iron (Fe), Copper (Cu) and Zinc ( $\mathrm{Zn})$ content, while $P$. pedicellatum has high Calcium (Ca) and Sodium ( $\mathrm{Na}$ ) content. The high mineral elements content of A. gayanus made the grass more useful for grazing and feeding of livestock. The high $\mathrm{Ca}$ content of $P$. pedicellatum may account for its high $\mathrm{Cf}$ content as $\mathrm{Ca}$ forms structural components of cell walls and membranes.
\end{abstract}

Keywords: Nutrients content, Andropogon gayanus, Pennisetum pedicellatum, Shagari LGA.

\section{INTRODUCTION}

The fodder given to animals is supposed to serve some specific purposes. Therefore, the value of any fodder crop depends on its nutritional content and palatability. Thus, the knowledge of constituents of animal feed is central to animal production and productivity. Nutrients are feed components that are utilized by animals after digestion and absorption have taken place (McDonald et al., 1998). They are also substances that are required for the nourishment of an organism, providing a source of energy and structural components. In animals, they form part of the diet and include major nutrients such as crude protein, ether extract crude fibre and mineral elements. These nutrients must be bio-available to the animals (Hotchkiss and Potter, 1996). Livestock must therefore be fed appropriately throughout the year as the nutrients from fodder are converted into animal proteins that served as human food. Umunna and Orji (1991), stated that the low nutrient content of many forages is the most critical constraint to livestock production in Nigeria. The nutritional value of forage is individually and collectively affected by various factors, including genetic, edaphic, climatic, type and level of utilization, management and stage of growth. Nutrients composition of forages also varies from time to time and location to location (De Leeuw, 1979). Mineral elements are inorganic substances derived by plants through their roots which are the contact points with the soil. The mineral elements absorbed by plants are then converted into plant products. The latter are then fed to livestock for conversion into animal products (Payne, 1994, Martin and Roberts, 2000). These mineral elements are believed to have one or more catalytic functions in the cell (Biswas and Mukherjee, 1995).

Andropogon gayanus Kunth belongs to the family Poaceae and tribe Andropogoneae. It is indigenous and widely distributed throughout the Savanna areas of Nigeria and the rest of Tropical Africa. It is commonly known as Gamba grass and locally called Gombol in Fulfude. It is a tall, perennial grass, erect, tufted/tussock with stems 2-4 metres high. It has various tillers and abundant foliage especially during the rainy season (Akubundu, 1987; Chlleda and Crowder, 1982; Pagot, 1993). It is propagated by seeds, which are broadcasted or planted in rows and vegetatively by splitting the tufts. It is relatively free of major pests and diseases and is resistant to grazing and burning. These make it a useful grass for supporting large number of ruminant animals in Northern Nigeria. It is also one of the high yielding grasses in West Africa (Bogdan, 1977; Pagot, 1993).

Pennisetum pedicellatum Trin, belongs to the Poaceae family and tribe Paniceae. It is annual and commonly 
known as Kyasuwa grass. It is also indigenous and occurs naturally in tropical and subtropical Africa (Bogdan, 1977). The stem height ranges from 40 - 150 $\mathrm{cm}$ or more and in some cases may have up to 10 nodes. The stem is smooth, cylindrical, jointed and encircled by the leaf sheath. The leaves are borne on sheaths which arise at the nodes. This study was designed to compare the nutrient and mineral elements of $A$. gayanus and $P$. Pedicellatum with the hope of enhancing animal feed efficiency and productivity.

\section{MATERIALS AND METHODS}

The study was conducted at Gangam rangeland, Shagari LGA, Sokoto state. Sokoto is located on latitude $12: 00^{\circ}$ and $13.60^{\circ} \mathrm{N}$ and longitude $4.08^{\circ}$ and $6.50^{\circ} \mathrm{E}$. It lies at an altitude of $350 \mathrm{~m}$ above sea level (Kowal and Knabe, 2002). The research determined the nutrients and mineral elements content of A. gayanus Kunth and $P$. Pedicellatum Trin. The study involved two plot of $100 \mathrm{M}^{2}$ each of the rangeland demarcated using $100 \mathrm{~m}$ measuring tape and ranging poles. The study plots were sub-divided into 5 sub-plots of $10 \mathrm{M}^{2}$. In

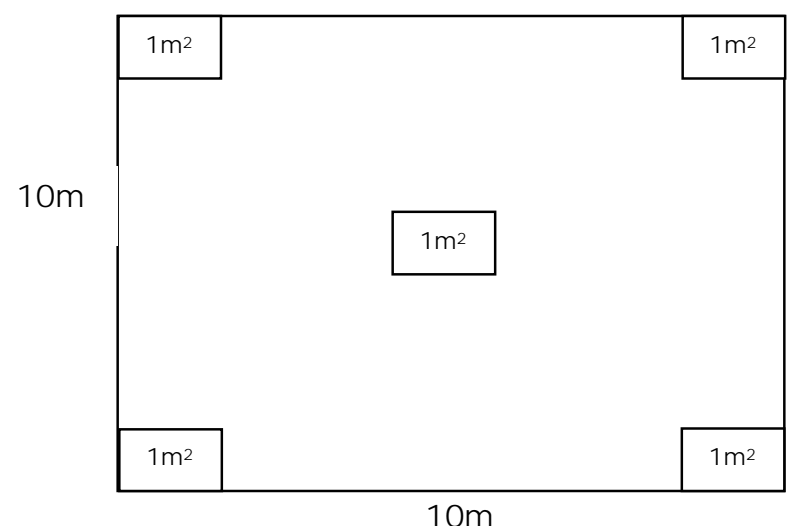

each sub-plot, 5 quadrats of $1 \mathrm{M}^{2}$ each were demarcated with one of them centrally placed and the remaining ones placed around it in the four directions of East, West, North and South.

Three quadrats of $\mathrm{M}^{2}$ each were randomly selected and harvested at ground level using knife and secateurs, after 6 weeks of growth. The samples were brought to the laboratory, mixed and chopped together. The samples were then dried in plus II Galen Kamp oven at $60^{\circ} \mathrm{C}$ to a constant weight using Mettler pm 16-k balance. This procedure continued at 2 weeks interval up to the end of the growing period as described by Krishna and Ranghan (1980) and Payne (1994), to determine the crude protein, Ether, Ash and Crude fibre and mineral elements $\mathrm{Ca}, \mathrm{P}, \mathrm{K}, \mathrm{Mg}, \mathrm{Na}, \mathrm{Fe}, \mathrm{Cu}$, and $\mathrm{Zn}$, contents. The results were subjected to analysis of variance (ANOVA), using statistical analysis system (SAS, 2003). The results obtained from $A$. gayanus and $P$. pedicellatum were compared as presented in tables 1 and 2.

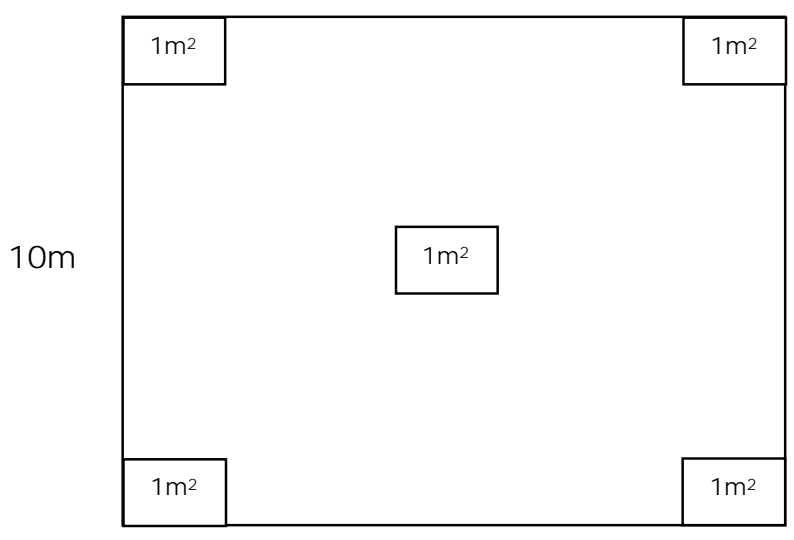

$10 \mathrm{~m}$

A. gayanus and $P$. pedicellatum Study Plot

Source: Gilbertson et al., (1990).

\section{RESULTS AND DISCUSSION}

The results in Table 1 reveal that $P$. pedicelatum had Cp content of 7.12 as against $4.19 \%$ of $A$. gayanus. The high $\mathrm{Cp}$ content of this grass species may be due to its nature of growth in which leaves were produced in abundance. Haggar and Ahmed (1992) reported that $\mathrm{Cp}$ is more concentrated in leaves. This could have enhanced the absorptive capacity of nitrogen element from the soil and subsequent formation of crude protein. This gives an indication of relatively high quality of this grass species as livestock feed than its counterpart. Proteins play an important role in Carbon- dioxide fixation during photosynthesis in plants. Grass proteins are particularly rich, have high biological value for growth and serve as structural element in all plant tissues. In the animal's body, they are utilized for growth, replacement of old, damaged or worn-out cells/tissues and formation of milk. They are particularly of great value to young growing animals and lactating ruminants. Similar findings were also reported by Chesworth (1992) and Payne (1994). On the other hand, A. gayanus had a little high Ee content of $9.20 \%$ when compared with $8.53 \%$ of $P$. pedicellatum. The difference was however not significant. Ether extract 
found mainly in the leaves of plants assists in the formation of protective layers, constituent of many membranes and major source of stored energy. These made the plant more energy efficient as animal feed.

The results further indicate that $P$. pedicellatum accumulated more $\mathrm{Cf}(32.72 \%)$ in contrast with $24.68 \%$ obtained from $A$. gayanus. This may be due to early production of stems and consolidation of fibrous tissues to support the plants when they are taller in advanced stage. The higher $\mathrm{Cf}$ content of $P$. pedicellatum was also reported by Mclloy 1976), Bogdan (1977); Duke (1983) and Payne (1994). The crude fibre makes the plants to be tensile, strong, stand erect for exposure to needed sunlight, maturation of seeds and easy harvesting. The roughage substances in $\mathrm{Cf}$ such as cellulose, hemicellulose and lignin hold water, soften stool, ensure proper working of the digestive system and reduce the incidence of colon cancer. It is required mainly by ruminants, and may also bind mineral elements in addition to increasing heat output of animals. These were also reported by Chesworth (1992), Payne (1994) and Hotchkiss and Potter (1996). In terms of Ash content, there was no significant $(P>$ 0.05) difference through $A$. gayanus had more. The difference could be due to high absorptive capacity of mineral elements from the soil by the plant and its perennial nature. The Ash content was within the range of $7-12 \%$ as observed by AFRIS (1980) and Duke (1983).

The mineral elements content of fodder is variable, depending on species type, stage of growth and soil. The result in Table 2 showed that $P$. pedicellatum had high calcium and this possibly made the plant to have more $\mathrm{Cf}$ as it is an important constituent of cell wall structure. It is also essential for growth of meristems and root hairs in pants and vital component of bones, teeth and plays a major role in coagulation of blood in animals (Hotchkiss and Potter 1996). The plant had also significantly high Sodium content which made the plant a useful livestock feed as it assists in controlling nerve impulses, normal absorption of sugars and amino acids from the digestive tract.

On the other hand, A. gayanus was found to be high in Phosphorus, Potassium and Magnesium content. This was attributed to its inherent absorptive capacity of these elements from the soil and their availability. Phosphorus is part of structural components of cell walls, membranes and plays a role in energy transportation in plant cells. These also made the plant vital for its energy value and proper bone/teeth formation when fed to the farm animals. Potassium helps in regulating permeability of cell membranes and the stem length. It also influences plants resistance against fungal and bacterial diseases. This grass species is also free from major pests and diseases. In the animal's body, it ensured correct maintenance of dissolved materials and $\mathrm{pH}$ equilibrium. Magnesium is a constituent of chlorophyll, chromosomes and helps in carbohydrates metabolism. This element is vital to farm animals because it prevents nervousness, staggering and hypo-magnesia as observed by Payne (1994) and Mc Donald et al., (1998).

Table 1: Proximate Composition of A.gayanus Kunth and $P$. pedicelletum Trin

\begin{tabular}{cccc}
\hline Parameter (\%) & $\begin{array}{c}\text { Andropogon } \\
\text { gayanus }\end{array}$ & $\begin{array}{c}\text { Pennisetum } \\
\text { pedicellatum }\end{array}$ & $\begin{array}{c}\text { Standard } \\
\text { Error }\end{array}$ \\
\hline $\begin{array}{c}\text { Crude protein } \\
(\mathrm{Cp})\end{array}$ & $4.19^{\mathrm{b}}$ & $7.12^{\mathrm{a}}$ & 0.42 \\
$\begin{array}{c}\text { Ether extract } \\
\text { (Ee) }\end{array}$ & $9.20^{\mathrm{a}}$ & $8.53^{\mathrm{a}}$ & 1.03 \\
Crude fibre (Cf) & $24.68^{\mathrm{b}}$ & $32.72^{\mathrm{a}}$ & 2.40 \\
Ash & $9.00^{\mathrm{a}}$ & $8.87^{\mathrm{a}}$ & 0.53 \\
\hline
\end{tabular}

Table 2: Mineral Content of $A$. gayanus and $P$. pedicellatum

\begin{tabular}{cccc}
\hline Mineral(ppm) & $\begin{array}{c}A . \\
\text { gayanus }\end{array}$ & $\begin{array}{c}P . \\
\text { pedicellatum }\end{array}$ & $\begin{array}{c}\text { Standard } \\
\text { Error }\end{array}$ \\
\hline $\mathrm{Ca}$ & 0.64 & 0.67 & 0.06 \\
$\mathrm{P}$ & $136.80^{\mathrm{a}}$ & $133.20^{\mathrm{b}}$ & 1.35 \\
$\mathrm{~K}$ & 735.38 & 677.33 & 66.89 \\
$\mathrm{Na}$ & $69.85^{\mathrm{b}}$ & $76.72^{\mathrm{a}}$ & 1.50 \\
$\mathrm{Mg}$ & 2.74 & 2.70 & 0.24 \\
$\mathrm{Fe}$ & $69.50^{\mathrm{a}}$ & $28.33^{\mathrm{b}}$ & 2.97 \\
$\mathrm{Cu}$ & 7.95 & 7.89 & 0.42 \\
$\mathrm{Zn}$ & $5.38^{\mathrm{a}}$ & $3.71^{\mathrm{b}}$ & 0.63 \\
\hline
\end{tabular}

Means followed by similar letters within a row are not significantly different at $5 \%$ level using LSD

The study found out that $A$. gayanus had high Iron, Copper and Zinc. Iron is essential for chlorophyll formation and activates a number of important enzymes in plants. It is also well distributed in plants tissues. It assists proper development of spleen, marrow and kidney in farm animals. The high Copper and Zinc content may have accounted for tallness of this species as these elements are necessary for the formation of growth promoting substance Auxin and stem elongation (Wild, 1996). Copper encourages reproductive capacity, 
bone and blood formation while Zinc is vital in maintaining normal skin colour, bone and liver development in farm animals. The high elements content of $A$. gayanus may be responsible for its high Ash content because Ash is the approximation of total mineral elements in fodder.

\section{CONCLUSION AND RECOMMENDATIONS}

In conclusion, $P$. pedicellatum was found to contain higher $\mathrm{Cp}$ and $\mathrm{Cf}$ whereas $A$. gayanus had relatively high Ash and Ee Similarly, A. gayanus had high amount of all the elements investigated except $\mathrm{Ca}$ and $\mathrm{Na}$ in which $P$. pedicellatum had more. It is important therefore, that these elements be readily available to plants in sufficient quantities for normal growth and development. The deficiency of these elements leads to retarded growth, chlorosis, weakening, poor root development, poor seed production, delayed maturity and low yield among others.

It is recommended that $P$. Pedicellatum be utilized for its high Crude protein, Crude fibre, Calcium and Sodium content while $A$. gayanus should be used for its Ether and mineral elements such as Phosphorus, Potassium, Magnesium, Iron, Copper and Zinc contents. The combination of these two grass species as animal feed will enable the farm animals to, a certain extent, meet their nutritional requirements. There is also the need to ensure that that all the essential mineral elements required by plants are available in the soil in sufficient quantities for enhanced fodder production and sustainable animal production particularly in Sokoto state and Nigeria in general.

\section{REFERENCES}

AFRIS (1980). A. gayanus and P. pedicellatum. htm, Animal Feed Resource Information System pp. 15.

Akubundu, I.O. (1987). Weed Science in the Tropics: Principles and Practices. 1 $1^{\text {st }}$ Edition John Willey and Sons, New York, USA. Pp. $28-103$.

Biswas, T.D. and Mukherjee S.K. (1995). Textbook of Soil Science $2^{\text {nd }}$ Edition, Tata McGraw-Hill Co. Ltd, New Delhi, India. Pp. $36-8,223-69$.

Bogdan, A.V. (1977). Pasture and Fodder Plants (Grassess and Legumes), Longman Press, New York, U.S.A. pp. 1-39; $229-31$.

Chesworth, J. (1992). The Tropical Agriculturist: Ruminant Nutrition, $1^{\text {st }}$ edition, Macmillan Press Ltd, London, pp. 5-25.
Chlleda, H.R. and Crowder, L.V. (1982). Tropical Grassland Husbandry, First edition, Longman, London, pp. 278-3359, 346-367.

De Leeuw, P.N. (1979). A Review of the Ecology and Fodder Resources of the Sub-Humid Zone, NAPRI. Symposium on Livestock production in sub-humid zone of West Africa, No. 32, Kaduna, Nigeria. Pp. 17-19.

Duke, A.J. (1983). Hand Book of Energy Crops, Unpublished. Pp. 1 - 4.

Martin E. and Roberts, S.H. (2000). Oxford Dictionary of Biology 4th Edition. Oxford Uni. Press, London. Pp. 214, 377.

Gilbertson, D.D., Kent, M. and Pyatt, F.B. (1990). Practical Ecology: Survey: Mapping and Data Analysis. $1^{\text {st }}$ Edition Unwin Hyman Ltd, London, U.K., pp. $75-83$.

Haggar R.J. and Ahmed, M.B. (1992). Seasonal Production of $A$. Gayanus: Changes in Crude Protein content and digestibility of leaf and stem portions. Samaru Research Bulletin. 145: 48 - 52.

Hotchkiss, H.J. and Potter, N.N. (1996). Food Science $5^{\text {th }}$ edition. Chapman and Hall Inc. New York, USA, pp. $30-63$.

Kowal, J.M and Knabe, D.T. (2002). An Agro Climatological Atlas of the Northern State of Nigeria. ABU Press, ABU Zaria, p. 128.

Krishna, G. and Ranjhan, S.K. (1980). Laboratory Manual for Nutrition Research, Vikas Publishing House, Sahitated, India, pp. 22-63.

McDonald, P., Edwards, R.A. and Green Hagh J.F.D. (1998). Animal Nutrition, $5^{\text {st }}$ edition Longman Group Ltd, London. Pp 434-444.

McLloy, R.J. (1976). An introduction to tropical grassland husbandry $2^{\text {nd }}$ edition. Oxford University Press, London; pp. 3 -113.

Pagot, J. (1993). Animal Production in the Tropics, $1^{\text {st }}$ edition, Macmillan Press, London, pp. 163 -181; $224-225$.

Payne, W.J.A. (1994). An Introduction to Animal Husbandry in the Tropics. $4^{\text {th }}$ edition, London Scientific and Technical, London. Pp. 87-112.

SAS (2003). Statistical Analysis System (SAS/STAT). Institute Inc. Guide for Personal Computers, Version $6^{\text {th }}$ edition, Carry N.C., U.S.A. pp. 967978.

Umunna, N.N. and Orji, P.A. (1993). The natural feed resources in Nigeria. In: Adamu, A.M., A. Mani, O.A. Osinowo, K.B. Adeoye and E.O. Ajileye (Eds.). Forage Production and Utilisation in Nigeria. Proceedings of National Workshop 
Waziri et al.: A Comparative Analysis of Nutrients and Mineral Elements Content of Andropogon gayanus Kunth and...

Organised by the National Livestock Project Division (NLPD), Federal Ministry of Agriculture and Natural Resources, Kaduna, Nigeria. Pp. 1631.
Wild, A. (1996). Soil and the Environment: An Introduction, Cambridge University Press, London. U.K. pp. 35-42. 